\title{
Stress Models of Depression: A Question of Bad Timing
}

\author{
Sarah Delcourte, Ouria Dkhissi-Benyahya, Howard Cooper, and Nasser Haddjeri
}

DOI:http://dx.doi.org/10.1523/ENEURO.0045-17.2017

INSERM, Stem Cell and Brain Research Institute U1208, University of Lyon, Université Claude Bernard Lyon 1, 69500 Bron, France

Key words: 5d-FSSM; animal model; depression; forced swimming; rodent; stress

Current antidepressant pharmacotherapy remains unsatisfactory because of its limited adherence and partial therapeutic efficacy. Accordingly, there is a crucial need of validated animal models that fully reflect the nature of the disease and do not only separate facets of the disorder.

We read with great interest the recent publication of Mul et al. (2016) reporting that, although the $5 \mathrm{~d}$ forced swimming stress model (5D-FSSM) of depression effectively increased floating behavior for 4 weeks, other depressivelike indexes, such as the sucrose preference test, were unaltered. Hence, they conclude that the 5D-FSSM model lacks "construct or face validity to model human depression."

As these data clearly contrast with those from previous published studies (Sun et al., 2011; Serchov et al., 2015), an obvious question is why? We propose that the study of Mul et al., (2016; as well as certain other studies) fails to take into account a critical factor: the time of day at which the swimming stress tests are conducted. In contrast to the study of Mul et al. (2016), who performed stress tests during the light phase when mice are inactive and normally sleep, we and others (Sun et al., 2011) have found stable depressive-like behaviors when the 5D-FSSM is conducted during the dark phase [zeitgeber time 14 (ZT14)] when nocturnal mice are active, but not at ZT1 during the light (inactive) resting phase (Fig. 1). These data clearly show that the time of stress is crucial for the induction of the depressive-like behavior.

Daily variations in anxiety-like behavior are also observed in rodents. Nakano et al. (2016) showed in C57BL/6 mice a rhythmic expression of anxiety-like be-
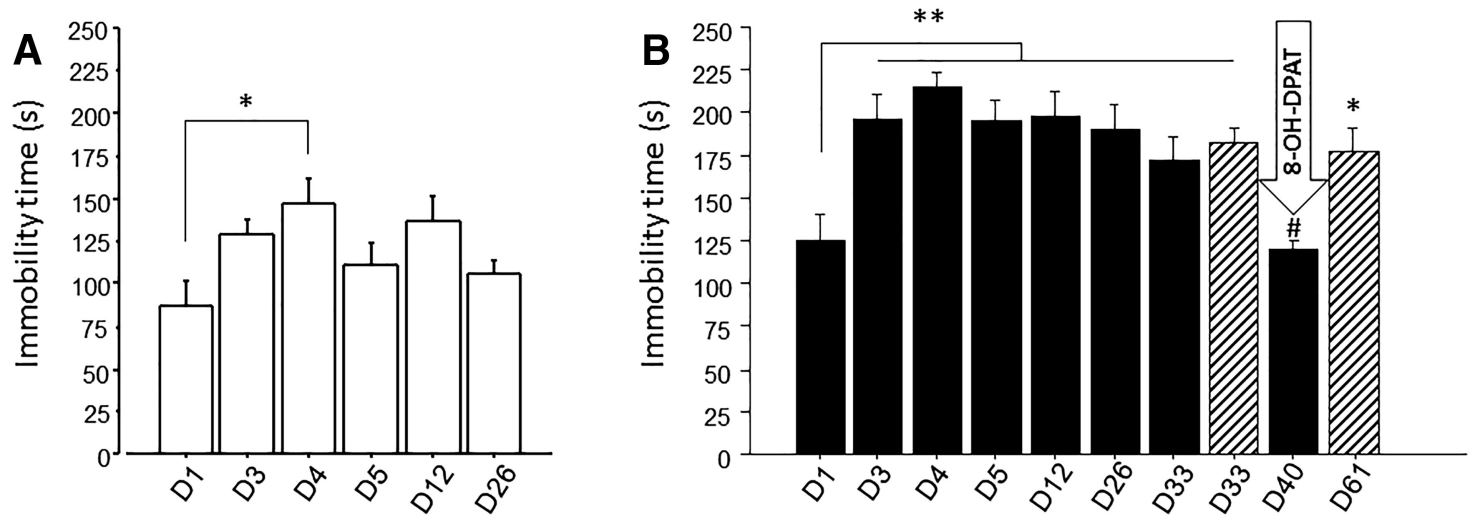

Figure 1. Immobility time in 5d-FSSM. A, B, Six-week-old C57BL/6 mice were forced to swim on 5 successive days (D) for 10 min at ZT1 $(\boldsymbol{A} ; n=6)$ or ZT $14(\boldsymbol{B} ; n=6)$ following the advice of Sun et al. (2011). Animals were then tested on days 12 and 26 . The immobility time was measured over the 10 min of swimming, but only the first 4 min were analyzed. A, Repeated one-way ANOVA revealed an effect of time: $* p<0.01$ vs day 1 ; post hoc Tukey-Kramer test showed a difference between D1 and D4. B, On day 40, mice $(n=6)$ received injections of 8-OHDPAT ( $1 \mathrm{mg} / \mathrm{kg}$, i.p.), a prototypical 5-HT1A receptor agonist, 30 min before the session. Another group (striped bar, $n=6$ ) did not receive 8-OHDPAT injection or undergo swim stress on day 40 but was forced to swim again on day 61 . Repeated one-way ANOVA showed a main effect of time. $* * p<0001, * p<0.05$ vs day 1 , \#p $<0.05$ vs D61. Immobility time was significantly shorter on day 1 than on days 3-33. The injection of 8-OHDPAT significantly decreased the immobility time. Results are expressed as the mean values \pm SEM. 
havior with increased anxiety-like behavior in the early part of the dark phase. A recent study (Ben-Hamo et al., 2016) using circadian desynchrony to induce depression like-behaviors in rats further revealed opposite responses of behavioral despair according to whether the forced swim test was performed during the light or the dark phase. Similar chronobiological responses have also been described by Ushijima et al. (2005), who showed that the effects of antidepressants are weak during the light phase but potent during the dark phase. In humans as well, circadian variation of mood is a characteristic feature in depressed patients (Peeters et al., 2006). Hence, appropriate timing is essential to accurately assess anxiety- and depressive-like behaviors in rodents and humans.

The importance of time-of-day (circadian) effects on the etiology of mood disorders and the timing of drug treatments (chronotherapy) as well as of the significant role of clock genes (Landgraf et al., 2014) has been increasingly

Received February 8, 2017; accepted March 22, 2017; First published April 14, 2017

The authors declare no competing financial interests.

Author Contributions: S.D., O.D.B., H.C., and N.H. designed research; S.D. performed research; S.D., O.D.B., and N.H. analyzed data; S.D., O.D.B., H.C., and N.H. wrote the paper.

This research was supported by INSERM and Claude Bernard UniversityLyon 1, France.

Acknowledgments: We thank Renaud Rovera for technical assistance.

Correspondence should be addressed to Nasser Haddjeri, Institut Cellule Souche et Cerveau, INSERM U846, 18 Avenue du Doyen Jean Lépine, 69675 Bron Cedex. E-mail: nasser.haddjeri@inserm.fr.

DOI:http://dx.doi.org/10.1523/ENEURO.0045-17.2017

Copyright (C) 2017 Delcourte et al.

This is an open-access article distributed under the terms of the Creative Commons Attribution 4.0 International license, which permits unrestricted use, distribution and reproduction in any medium provided that the original work is properly attributed. recognized (Turek, 2016). We thus caution that, depending on the day-night activity pattern of the animal, negative results can be a question of inappropriate timing.

\section{References}

Ben-Hamo M, Larson TA, Duge LS, Sikkema C, Wilkinson CW, de la Iglesia HO, González MM (2016) Circadian forced desynchrony of the master clock leads to phenotypic manifestation of depression in rats. eNeuro 3:1-13. CrossRef

Landgraf D, McCarthy MJ, Welsh DK (2014) The role of the circadian clock in animal models of mood disorders. Behav Neurosci 128: 344-359. CrossRef Medline

Mul JD, Zheng J, Goodyear LJ (2016) Validity assessment of 5 day repeated forced-swim stress to model human depression in young-adult C57BL/6J and BALB/cJ mice. eNeuro 3:1-9. CrossRef

Nakano JJ, Shimizu K, Shimba S, Fukada Y (2016) SCOP/PHLPP1 $\beta$ in the basolateral amygdala regulates circadian expression of mouse anxiety-like behavior. Sci Rep 6:33500. CrossRef Medline

Peeters F, Berkhof J, Delespaul P, Rottenberg J, Nicolson NA (2006) Diurnal mood variation in major depressive disorder. Emotion 6:383-391. CrossRef Medline

Serchov T, Clement HW, Schwarz MK, lasevoli F, Tosh DK, Idzko M, Jacobson KA, de Bartolomeis A, Normann C, Biber K, van Calker D (2015) Increased signaling via adenosine A1 receptors, sleep deprivation, imipramine, and ketamine inhibit depressive-like behavior via induction of Homer1a. Neuron 87:549-562. CrossRef Medline

Sun $P$, Wang F, Wang L, Zhang $Y$, Yamamoto R, Sugai T, Zhang Q, Wang Z, Kato N (2011) Increase in cortical pyramidal cell excitability accompanies depression-like behavior in mice: a transcranial magnetic stimulation study. J Neurosci 31:16464-16472. CrossRef Medline

Turek FW (2016) Circadian clocks: not your grandfather's clock. Science 354:992-993. CrossRef Medline

Ushijima K, Sakaguchi H, Sato Y, To H, Koyanagi S, Higuchi S, Ohdo $S$ (2005) Chronopharmacological study of antidepressants in forced swimming test of mice. J Pharmacol Exp Ther 315:764770. CrossRef Medline 